\title{
SENTRA BUDIDAYA DAN KREASI MUSIK BAMBU DI KELURAHAN SETU, JAKARTA TIMUR
}

\author{
Jacinta Karina ${ }^{1)}$, Suryono Herlambang ${ }^{2)}$ \\ 1) Program Studi S1 Arsitektur, Fakultas Teknik, Universitas Tarumanagara, jacintak.ta@stu.untar.ac.id \\ 2) Program Studi S1 Arsitektur, Fakultas Teknik, Universitas Tarumanagara, suryonoh@ft.untar.ac.id
}

\begin{abstract}
Abstrak
Kota merupakan tingkatan administratif dari sebuah pemerintahan. Di dalamnya terdapat fungsi - fungsi yang kompleks dan dihuni oleh masyarakat dengan berbagai aktivitas dan rutinitas, serta menjadi wadah bagi segala aktivitas, mata pencaharian, hunian, perdagangan, industry, pusat pemerintahan, dan lain - lain. Dari 24 jam, sebagian besar dihabiskan untuk bekerja dan belajar, sedangkan sebagian kecil dipergunakan untuk bersantai atau beristirahat. Jakarta merupakan ibukota negara Indonesia, disebut sebagai kota metropolitan, karena menjadi pusat politik, ekonomi, pariwisata, sosial budaya masyarakat, dan lain - lain. Arsitektur dalam kota menunjukkan citra kota tersebut, menjadikan ikon dan symbol tertentu, serta dapat menaikkan status sosial kota dan lingkungan binaan. Bidang pariwisata dalam karya arsitektur diharapkan menjadi destinasi wisata bagi warga Jakarta, dan sekitarnya. Untuk itu penulis mengkaji dan menganalisa Sentra Budidaya dan Kreasi Musik Bambu di Kelurahan Setu, Jakarta Timur dengan menggunakan metode pemikiran desain. Saat ini, bambu mulai diperhitungkan oleh pemerintah, terutama Badan Ekonomi Kreatif (BEKRAF) sebagai seni, bahan jadi untuk kehidupan sehari - hari, bahkan bangunan berstruktur dan material utama dari bambu. Peluang bambu di kemudian hari akan bertambah tinggi, bahkan akan perlahan menggantikan kayu karena dengan teknik - teknik tertentu, bambu lebih unggul daripada kayu, dan mudah diperbaharui. Dalam perdagangan dunia saat ini, bambu adalah salah satu komoditas paling strategis dan mempengaruhi perekonomian dunia.
\end{abstract}

Kata kunci: bambu, budidaya, musik, pariwisata, pemikiran desain

\begin{abstract}
City is the level of government administration. In it there are complex functions and inhabited by the community with various activities and routines, as well as being a forum for all activities, livelihoods, housing, trade, industry, government centers, and others. From 24 hours, most is spent working and studying, while a small portion is used to relax or rest. Jakarta is the capital of Indonesia, referred to as a metropolitan city, because it is the center of politics, economics, tourism, social culture, etc. Architecture in this city shows the image of the city, makes certain icons and symbols, and can improve the social status of the city and the built environment. The field of tourism in architectural works is expected to become a tourist destination for residents of Jakarta and its surroundings. For this reason, the authors reviewed and analyzed the Center for Cultivation and Creation of Bamboo Music in Setu Village, East Jakarta using the method of design thinking. At present, bamboo is being considered by the government, especially the Creative Economy Agency (BEKRAF) as an art, finished materials for everyday life, even structured buildings and main materials from bamboo. Bamboo opportunities will grow higher in the future, and will even gradually replace wood because with certain techniques, bamboo is superior to wood, and easily renewed. In today's world trade, bamboo is one of the most strategic commodities and affects the world economy.
\end{abstract}

Keywords: bamboo, cultivation, design thought, music, tourism

\section{PENDAHULUAN} Latar Belakang

Arsitektur pariwisata adalah arsitektur yang bergerak sebagai daya tarik pariwisata dan tidak terbatas pada suatu periode waktu, atau gaya arsitektur tertentu. Arsitektur pariwisata berdampak bagi insider (penduduk lokal) dan juga outsider (pengunjung atau wisatawan). 
Dengan adanya arsitektur pariwisata, diharapkan dapat menyalurkan kebutuhan wisata para penduduk dan pengunjung di daerah tersebut, serta menaikkan citra kota menjadi lebih baik.

Bambu masuk dalam golongan family Gramineae (rumput) yang dibagi ke dalam lima suku, yaitu Dendrocalaminae, Melocanninae, Bambusinae, Arundinaiiae, dan Puellinae. Saat ini, bambu mulai diperhitungkan oleh pemerintah, terutama Badan Ekonomi Kreatif (BEKRAF) sebagai seni, bahan jadi untuk kehidupan sehari - hari, bahkan bangunan berstruktur dan material utama dari bambu. Peluang bambu di kemudian hari akan bertambah tinggi, bahkan akan perlahan menggantikan kayu karena dengan teknik - teknik tertentu, bambu lebih unggul daripada kayu, dan mudah diperbaharui. Dalam perdagangan dunia saat ini, bambu adalah salah satu komoditas paling strategis dan mempengaruhi perekonomian dunia. Sebagai komoditas ekspor, bambu Indonesia memang menjadi salah satu primadona setelah Tiongkok. Data statistik tahunan sejak 1999-2012 mengenai perdagangan bambu dan rotan yang dirilis INBAR menunjukkan bahwa Tiongkok, Indonesia, dan Vietnam masih menjadi tiga negara Asia pemasok bambu ekspor terbesar saat ini. Total ekspor ketiganya mencakup sepertiga volume ekspor bambu dunia.

Indonesia terkenal akan keanekaragaman flora dan fauna yang tersebar dari Sabang hingga Merauke. Salah satu keanekaragaman flora di Indonesia, yaitu tanaman bambu. Bambu sebagai bahan bangunan biologis dapat didapatkan hampir di seluruh Indonesia. Bambu biasanya ditanam di halaman, lereng - lereng sepanjang sungai, jurang, dan sebagainya. Persebaran tanaman bambu dapat ditemukan di Benua Asia, Afrika, Amerika, beberapa spesies di Benua Australia. Di Indonesia, persebaran bambu sudah mencapai lebih dari 5.000 rumpun, seperti terlihat pada gambar 2.3. Bambu termasuk dalam keluarga rumput - rumputan yang memiliki kekuatan sekaligus kelenturan dengan beragam manfaat. Jenis bambu yang tahan lama, diantaranya :
a. Jenis besar
: bambu petung dan bambu gombong
b. Jenis sedang
: bambu andong dan bambu temen
c. Jenis kecil
: bambu apus dan bambu tali

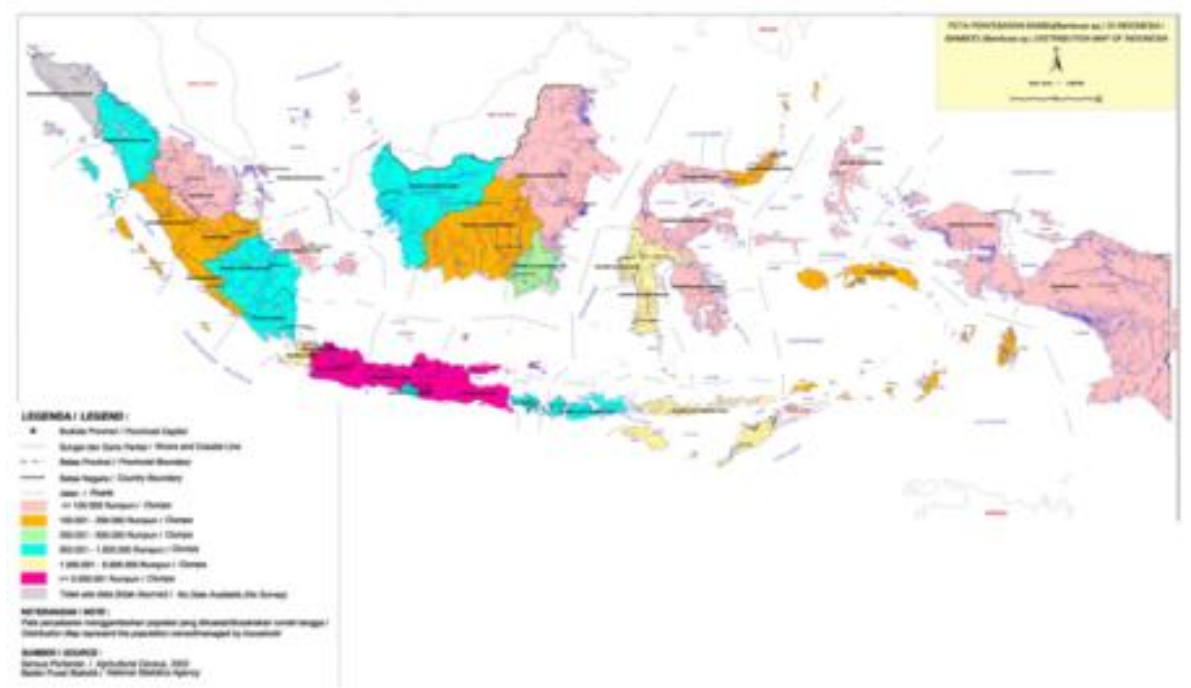

Gambar 1. Peta Persebaran Bambu di Indonesia

Bambu sangat mudah didapat dan sering dijadikan sebagai bahan bangunan sejak dahulu. Selain itu, bambu juga dipergunakan sebagai alat pertanian, kerajinan, alat musik, dan makanan. Setiap bagian dari bambu dapat diolah dan dimanfaatkan untuk kebutuhan tertentu. Bambu juga sering dipakai sebagai pencegah abrasi dan erosi sehingga biasanya ditemukan di daerah pesisir laut, karena dapat menahan pengikisan tanah dengan memperkuat ikatan partikel air. Selain bermanfaat, bambu juga memiliki kekurangan, diantaranya mudah dibelah, 
mudah terbakar, peka terhadap rayap dan bubuk, rongga - rongga menjadi hunian bagi tikus. Namun apabila kekurangan ini dapat diselesaikan secara konstruktif, bambu akan menjadi bahan bangunan yang amat bermanfaat.

Manfaat bagian - bagian tanaman bambu di kehidupan sehari - hari :

\section{a. Akar}

Tanaman bambu biasanya ditanam di sekitar pinggiran sungai, laut karena bermanfaat sebagai penahan erosi dan pencegah banjir. Akar bambu juga dapat dimanfaatkan untuk menangani limbah beracun akibat merkuri. Serabut dari akar bambu menyaring air sehingga baik untuk penyaringan air di sumur air bersih.

b. Daun

Daun bambu biasanya mencerminkan sifat estetis dari tanaman bambu, sehingga sering dijadikan sebagai tanaman hias. Selain itu, sifat daun bambu yang dingin seringkali dijadikan sebagai obat demam, dan obat darah tinggi. Daun bambu juga sering dimanfaatkan sebagai pakan ternak. Bagian daun dari bambu juga bermanfaat sebagai sumber oksigen dan menyerap karbon.

c. Batang

Batang bambu paling sering dijumpai di kehidupan sehari - hari. Batang bambu dapat dijadikan sebagai saluran air, kerajinan, bahan bangunan, alat dapur atau alat makan, tanaman hias, alat musik, furniture, bahan baku kertas, dan lain - lain.

\section{d. Rebung}

Rebung dikenal sebagai bahan pangan karena memiliki kandungan protein, serat, selulosa, vitamin (vitamin A, B6, E) dan mineral.

\section{METODE}

Metode pembahasan dalam penulisan ini menggunakan metode penelitian kualitatif yang bersifat inovatif dan eksperimental. (Curedale, 2013) Metode kualitatif ini dilakukan dengan cara pengamatan lokasi dan melakukan survey, wawancara kepada pihak terkait, serta studi kasus.

Metode pemikiran desain yang dipakai adalah people focused berdasarkan human needs. Pemikiran desain ini memiliki pendekatan yang berpusat kepada masyarakat untuk mengetahui kebutuhan, keinginan, serta respon masyarakat dengan solusi desain yang inovatif. Terdapat beberapa kriteria metode pemikiran desain ini dengan proyek, seperti terlampir pada gambar.

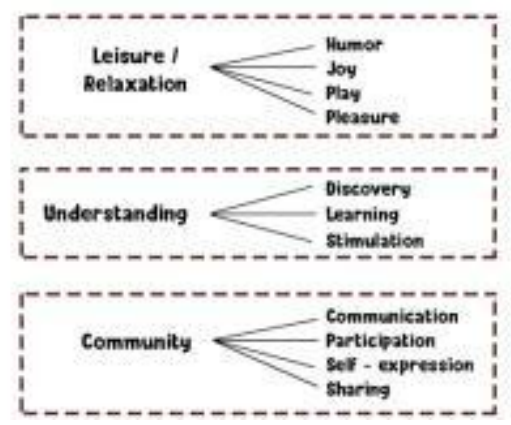

Gambar 2. Kategori Human Needs

\section{DISKUSI DAN HASIL}

Pada bagian Kajian Literatur, penulis perlu menuliskan kajian literatur (teori, buku, jurnal, dII) yang digunakan sebagai landasan analisis atau desain. Seluruh referensi yang digunakan harus tercantum dalam daftar referensi.

Jakarta sebagai ibu kota negara Indonesia merupakan kota yang padat aktivitas penduduknya. Mayoritas penduduk Jakarta merupakan penduduk usia produktif, yang masih aktif bekerja dan beraktivitas, sedangkan waktu untuk relaksasi atau beristirahat lebih sedikit. 
Berawal dari Batavia, Kota Tua Jakarta, yang juga merupakan padat aktivitas terutama di bidang pemerintahan dan perdagangan. Saat ini, aktivitas Jakarta berkembang luas menjadi komersil, pemerintahan, perkantoran, hiburan komersial (pusat perbelanjaan), dan lain - lain. Sayangnya, aktivitas penduduk Jakarta tidak diimbangi dengan pelepasan penat penduduknya. Mayoritas masyarakat menghabiskan akhir pekan di pusat perbelanjaan, sehingga saat ini pusat perbelanjaan menjadi banyak di setiap daerah di Jakarta, terutama di sekitar hunian. Pusat perbelanjaan menjadi daya tarik masyarakat karena mengusung konsep "one stop shopping", yang berarti di satu tempat terdapat seluruh pemenuhan kebutuhan masyarakat. Namun, keadaan pusat perbelanjaan di Jakarta tidak memenuhi kebutuhan penduduk untuk melepas penat. Biasanya tempat berelaksasi adalah tempat yang cenderung sepi, tenang, dan berbeda dari rutinitas yang dijalani. Oleh karena itu, pusat hiburan diperlukan di kota Jakarta, terutama yang memberikan edukasi bagi pengunjungnya..

Menurut data dari Badan Pusat Statistik Jakarta Timur tahun 2014, Kelurahan Setu, Cipayung (gambar 3.1), memiliki jumlah penduduk 260.578 jiwa dari total jumlah penduduk 2.817.994 jiwa terlampir dalam gambar 3.2. Dari total jumlah penduduk di Jakarta Timur, terlampir dalam gambar 3.4 , sebanyak $4.2 \%$ penduduk tidak memiliki pekerjaan (pengangguran) dan $26.7 \%$ bekerja di bidang industry.

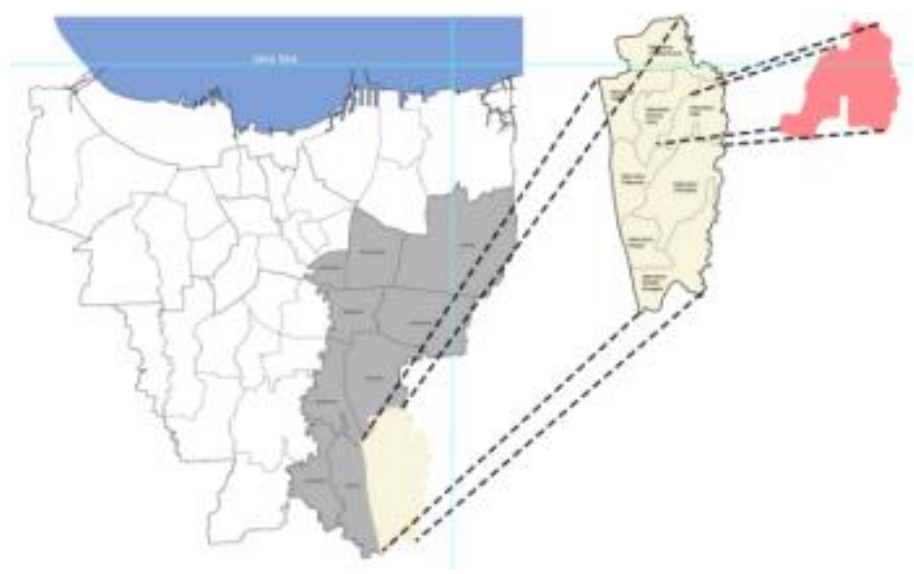

\section{Analisis Program Kegiatan}

Gambar 3. Kelurahan Setu

Sentra Budidaya dan Kreasi Musik Bambu berada di Taman Bambu, Setu, Jakarta Timur. Taman Bambu merupakan salah satu taman yang berfungsi sebagai hutan hujan, yaitu hutan yang menampung air hujan. Melihat potensi dari taman ini, baiknya ada sarana pendukung untuk mengembangkan potensi dari tapak, yaitu bambu. Bambu sendiri memiliki beragam manfaat dari setiap bagian tanamannya sehingga harus dimanfaatkan secara maksimal untuk menaikkan nilai ekonomi dan sosial masyarakat sekitar.

Aktivitas yang dirancang di Sentra Budidaya dan Kreasi Musik Bambu ini adalah :

a. Budidaya Bambu

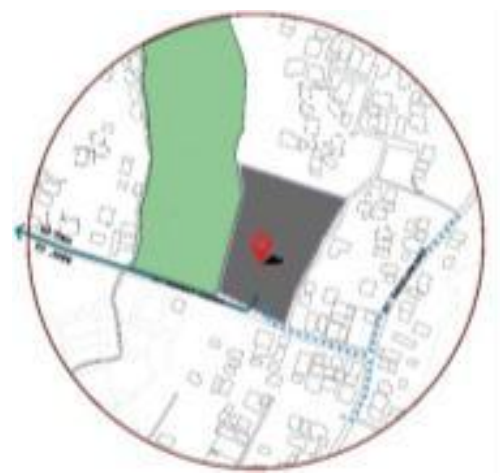

Gambar 4. Lokasi Tapak 
Kegiatan penanaman berbagai jenis tanaman bambu di tapak eksisting Taman Bambu untuk memaksimalkan potensi tapak eksisting. Untuk menunjang kegiatan budidaya ini, disediakan juga sarana pelatihan untuk pengolahan bambu menjadi barang pakai sehari - hari. Lokasi budidaya bambu terletak di tapak eksisting Taman Bambu yang berada di sebelah tapak Sentra Budidaya dan Kreasi Musik Bambu, seperti terlihat pada gambar lokasi tapak berwarna hijau. Hasil budidaya ini digunakan sebagai bahan baku pelatihan bambu. :

b. Workshop Bambu

Pengunjung dapat mengenal bambu dari jenis, cara pengolahan, dan alat music bambu dalam satu ruangan. Setelah itu, pengunjung dapat melihat cara pengolahan bambu dari hasil budidaya di Taman Bambu menjadi berbagai alat music dengan bahan dasar bambu.. Kegiatan pengolahan bambu menjadi alat music ini dapat diikuti oleh pengunjung. Pengolahan bambu ini dilakukan setiap mingguan untuk membuka lapangan pekerjaan bagi masyarakat sekitar, sehingga dapat menggerakan ekonomi daerah. Apabila pengunjung mengikuti workshop, pengunjung dapat membawa pulang hasil karyanya.

Pelatihan bambu ini dibagi ke dalam 2 kategori, yaitu kelas kecil yang ditujukan untuk pengunjung atau pemula, dan kelas besar yang ditujukan bagi masyarakat atau pekerja yang hendak belajar cara pengolahan bambu, serta menjadi ruang kerja bagi pekerja. Pelatihan kelas kecil diadakan setiap hari, dengan jadwal :

- Senin-Jumat : 09.00-11.00

- Sabtu - Minggu : $09.00-11.00$ dan $13.00-15.00$

Materi kelas pelatihan dapat dipilih berdasarkan usia :

- Kelas Bambu Anak (6-12 tahun) : membuat layangan

- Kelas Bambu Remaja (13-18 tahun) : membuat vas bunga

- Kelas Bambu Muda (19-25 tahun) : membuat suling bambu

- Kelas Bambu Dewasa (26 tahun ke atas) : membuat angklung

Setiap kelas berkapasitas 16 orang. Setiap kelas memiliki satu orang pengajar dengan 1 pendamping setiap 4 orang murid pelatihan.

\section{c. Pagelaran Musik Bambu}

Pagelaran musik ini dilakukan oleh anggota Komunitas Bambu yang sudah terampil. Terdapat pertunjukan musik menggunakan beberapa alat musik berbahan dasar bambu dari seluruh Indonesia, diselingi tarian tradusional, dan di akhir acara, pengunjung diajak berpartisipasi dalam "Joged Bumbung" dan memainkan alat musik angklung bersama. Pagelaran music ini berlangsung selama 1 jam 30 menit, dengan jadwal :

- Senin-Jumat : :14.00-15.30

- Sabtu - Minggu : $10.00-11.30$ dan $14.00-15.30$

d. Kuliner Rebung

Pengunjung dapat menikmati sajian kuliner khas bambu, seperti rebung. Sajian kuliner ini diolah oleh masyarakat sekitar tapak yang tidak memiliki pekerjaan, sehingga membuka lapangan pekerjaan baru bagi masyarakat sekitar. Sistem cafetaria ini berupa kios makanan dengan jumlah 4 kios dikelola oleh masyarakat sekitar.

e. Souvenir Shops

Hasil - hasil kerajinan tangan dan barang kebutuhan sehari - hari karya pekerja budidaya bambu. Barang - barang yang dijual adalah barang kebutuhan sehari - hari, seperti vas bunga, tatakan piring gelas, partisi, rumah lampu, bangku santai, gantungan baju. Serta buah tangan, seperti gantungan kunci, kalung angklung, tempat tisu, kipas.

\section{Analisa Program Kebutuhan Ruang}

Untuk menunjang segala aktivitas di Sentra Budidaya dan Kreasi Musik Bambu, ditentukan ruangan - ruangan untuk keperluan kegiatan, seperti terlampir pada gambar. Besaran ruang 
ini ditentukan dari kebutuhan dan jumlah pengguna, berdasarkan proses pemikiran desain human needs.

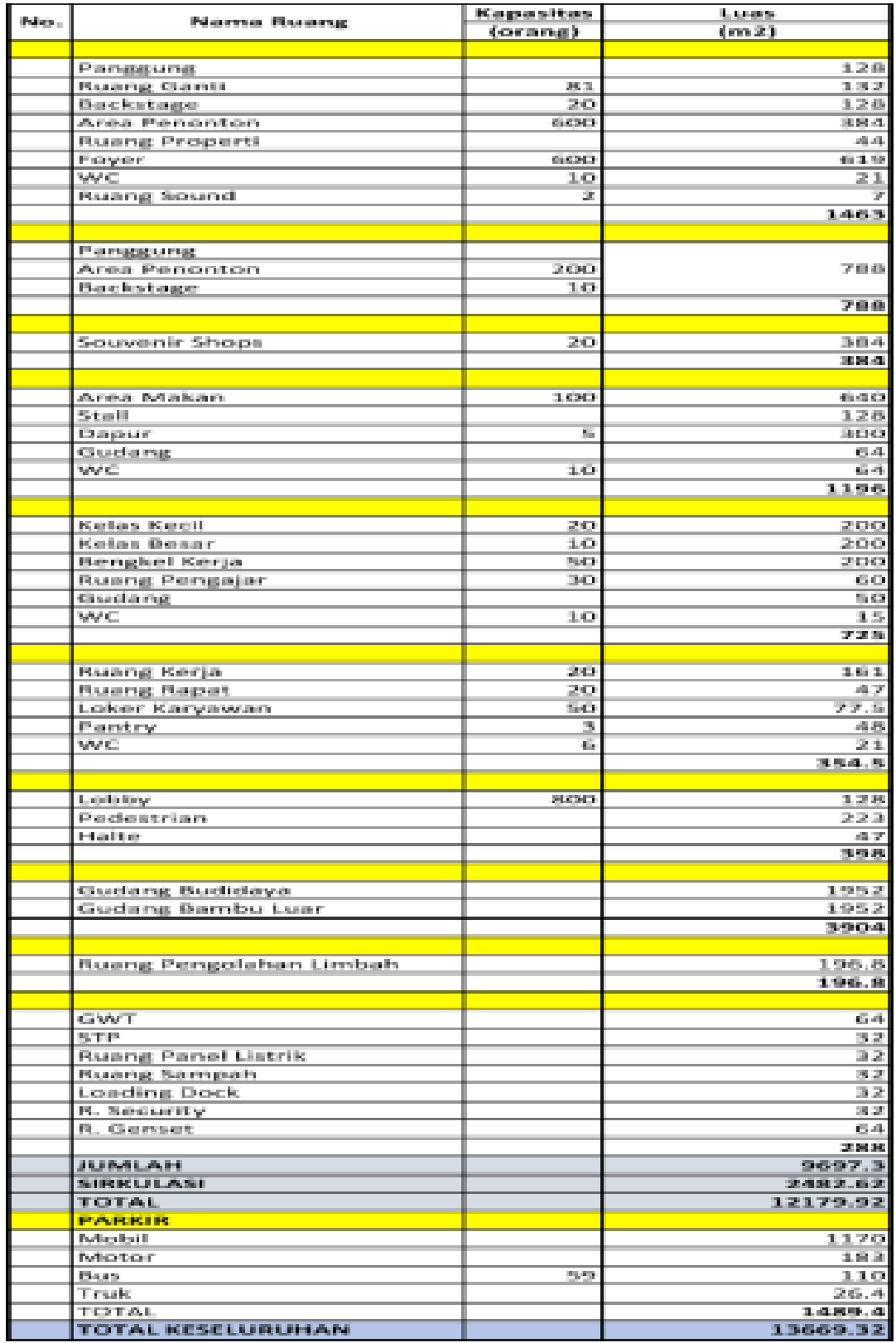

Gambar 5. Program Ruang

\section{Analisa Pemilihan Lokasi}

Tapak yang dipilih untuk Sentra Budidaya dan Kreasi Musik Bambu bersebalahan dengan Taman Bambu di Jalan Pagelarang, Setu, Cipayung, Jakarta Timur 13890. Lokasi ini dipilih karena cocok dengan ide awal proyek untuk mengangkat kembali popularitas bambu. Selain itu, Taman Bambu terletak di sepanjang Kali Sunter, sehingga cocok untuk ditanami tanaman Bambu untuk mencegah banjir, dan menyaring kotoran - kotoran dan limbah pada air sumur. Lokasi ini juga dekat dengan Taman Mini Indonesia Indah, dimana menjadi pusat pembelajaran yang lengkap, serta Bandar Udara Halim Perdanakusuma, sebagai salah satu pintu masuk pariwisata di Jakarta.

Taman Bambu eksisting akan diperbaiki dan dijadikan menjadi lahan budidaya bambu, serta dikembalikan fungsinya sebagai hutan hujan kota. Lahan seluas 1.5 hektar ini akan ditanami 5 jenis bambu yang dapat dipakai untuk kerajinan, yaitu bambu petung, bambu gombong, bambu andong, bambu temen, bambu apus, serta bambu tali. 


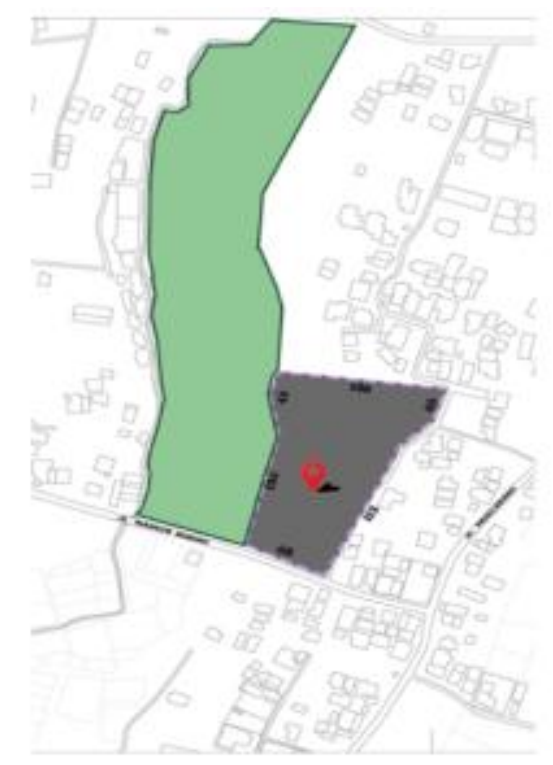

Gambar 6. Ukuran Tapak

Tapak ini berukuran $15.547 \mathrm{~m}^{2}$ berada di Jalan Mandor Munding, Setu, Cipayung dengan ketentuan tapak sebagai berikut :

$\begin{array}{ll}\text { KDB } & : 30 \\ \text { KLB } & : 0.90 \\ \text { KTB } & : 0 \\ \text { KB } & : 3 \\ \text { KDH } & : 45 \\ \text { Tipe } & : \text { Tunggal } \\ \text { PSL } & : \text { Kurang padat }\end{array}$

\section{Analisa Konsep Perancangan}

Organisasi ruang yang terbentuk dari Sentra Budidaya dan Kreasi Musik Bambu ini berdasarkan sirkulasi pengunjung dan kebutuhan industri bambu yang berjalan setiap hari. Zoning pembagian ruang juga dilakukan berdasarkan jalur sirkulasi dan kebutuhan pengunjung dan pekerja dari proyek ini. Secara bentuk, atap pada bangunan ini mencerminkan bentuk daun. Dua massa berbeda dihubungkan dengan amphitheater di lantai dasar, dan juga jembatan di lantai dua dan tiga.

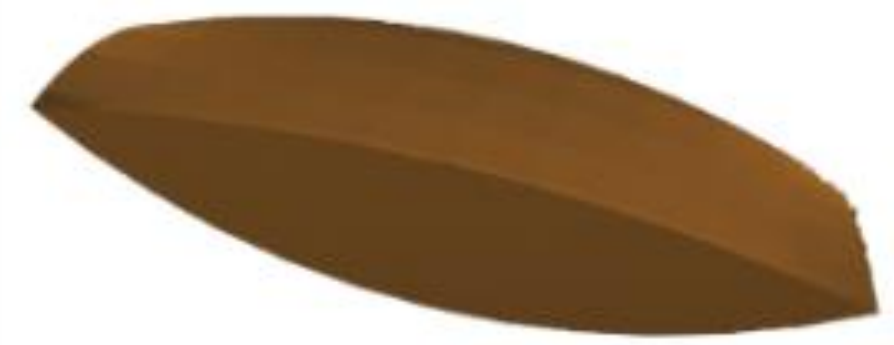

Gambar 7. Desain Atap

Bentuk atap pada bangunan ini dianalogikan seperti bentuk daun yang dinamis. Menggambarkan bahwa bambu ini juga bersifat dinamis, meskipun terlihat tradisional namun dapat digunakan untuk kebutuhan tradisional hingga modern. Barang kebutuhan sehari - hari pun dapat menggunakan bahan dasar bambu. 


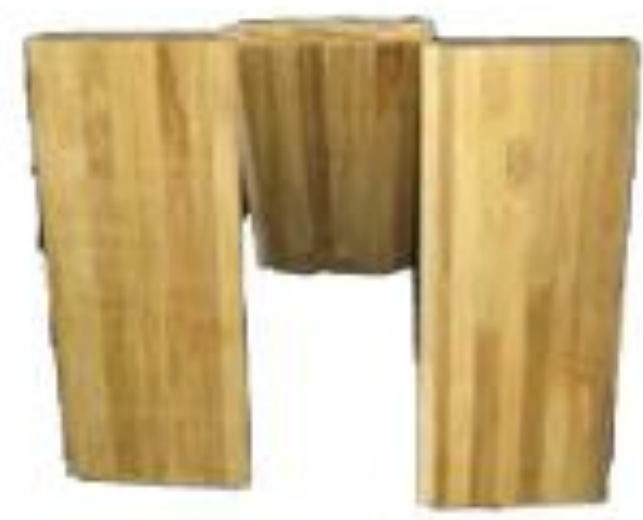

Gambar 8. Bambu Lamina

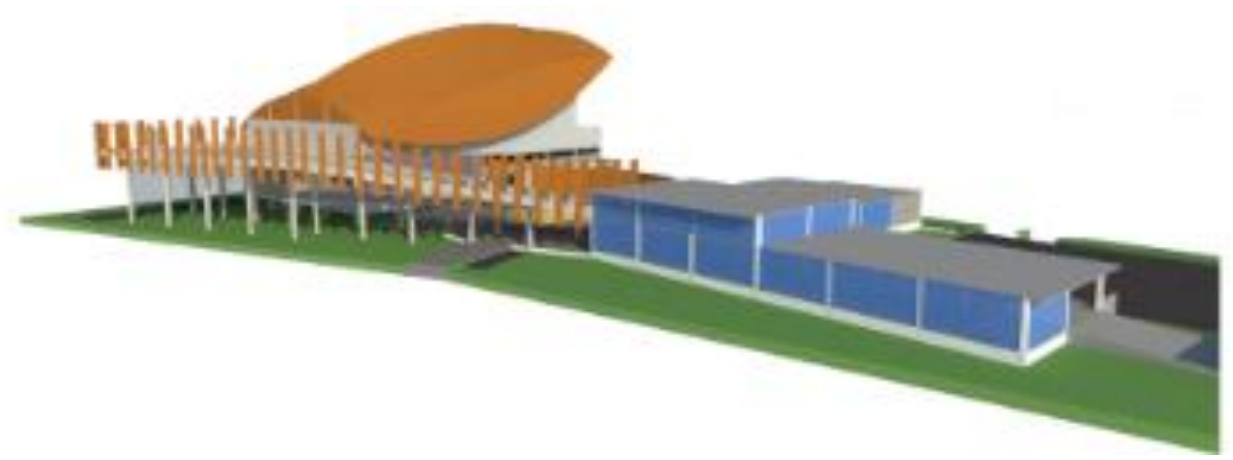

Gambar 9. Jembatan Perantara

Terdapat penghubung antara 2 massa, yaitu jembatan yang diberi aksen bambu dari bambu Lamina sebagai aksen pada railing jembatan. Jembatan ini juga berfungsi sebagai perantara antara massa depan yang bergaya modern dan massa belakang yang bergaya tradisional.

\section{Konsep Massa}

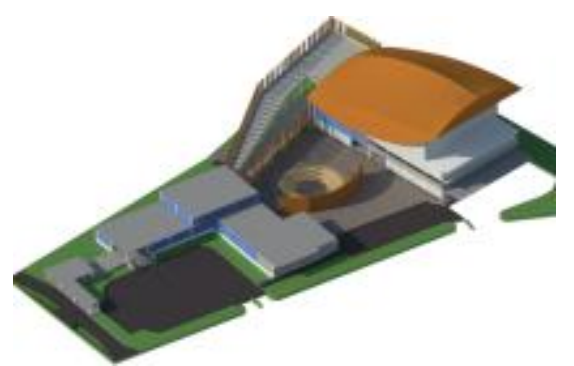

Gambar 10. Design Scheme
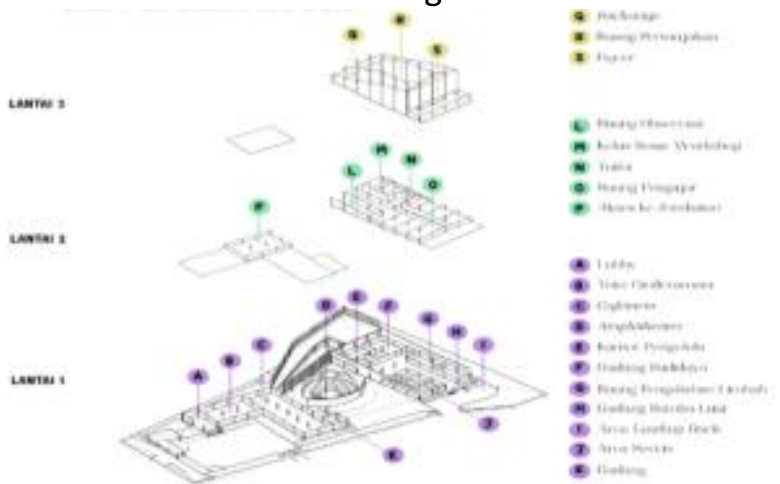

Gambar 11. Eksploded Denah 
Tapak proyek ini dilewati oleh dua jalan, yaitu Jalan utama yaitu Jalan Mandor Munding yang terletak di bagian depan tapak ini, dan jalan samping yaitu Gang Damai yang berada di sebelah kanan tapak ini. Jalan utama digunakan sebagai akses pejalan kaki dan juga akses shuttle bus dari TMII. Jalan utama memiliki lebar 7 meter, dan diperbesar ke arah dalam tapak, sehingga memiliki lebar 12 meter. Sedangkan untuk Gang Damai dipakai untuk jalur kendaraan (mobil dan motor), serta jalur servis.

Terdapat dua massa pada proyek ini, yaitu massa depan untuk ruang Souvenir Shops dan Cafetaria Bambu, serta loket penjualan tiket. Massa depan diperuntukan bagi kegiatan public, semua pengunjung dapat mengakses ruangan ini. Sedangkan massa di belakang lebih diperuntukkan bagi pengunjung berbayar atau yang telah mendaftar, serta pekerja budidaya. Di massa belakang, terdapat ruang kelas pelatihan, kantor pengelola, gudang budidaya, dan ruang pagelaran seni.

Terdapat penghubung antar dua massa, yaitu amphitheater yang bersifat publik dan terbuka setiap hari untuk pengunjung, maupun masyarakat sekitar yang ingin bersantai, menikmati suasana rindang di bawah pohon - pohon bambu. Amphitheater ini dapat digunakan oleh pihak mana saja, seperti sekolah - sekolah sekitar yang ingin mengadakan pertunjukan, atau sanggar yang membutuhkan tempat latihan, maupun pengunjung yang ingin makan dengan suasana outdoor.

Selain amphitheater, terdapat juga penghubung antar massa berupa jembatan. Jembatan ini menghubungkan lantai 2 massa depan dengan lantai 2 dan lantai 3 massa bagian belakang. Lantai dua massa belakang merupakan ruang pelatihan bambu. Sebelum berbelanja di Souvenir Shops, pengunjung diajak untuk melihat proses kerja mengolah bambu menjadi barang jadi, sehingga dapat menarik minat pengunjung untuk berbelanja. Sedangkan di lantai 3 massa belakang, terdapat ruang pagelaran seni musik bambu, yang menjadi program utama di proyek ini.

Jembatan ini juga menjadi salah satu icon di proyek ini. Selain karena fungsinya sebagai penghubung massa, jembatan ini juga dapat menjadi lokasi multi-event, misalnya untuk bazaar atau festival berkala, ataupun dapat didesain khusus untuk suatu acara tertentu, seperti Hari Musik Nasional, Peringatan Imlek, dan lain - lain.

\section{Desain Perancangan}

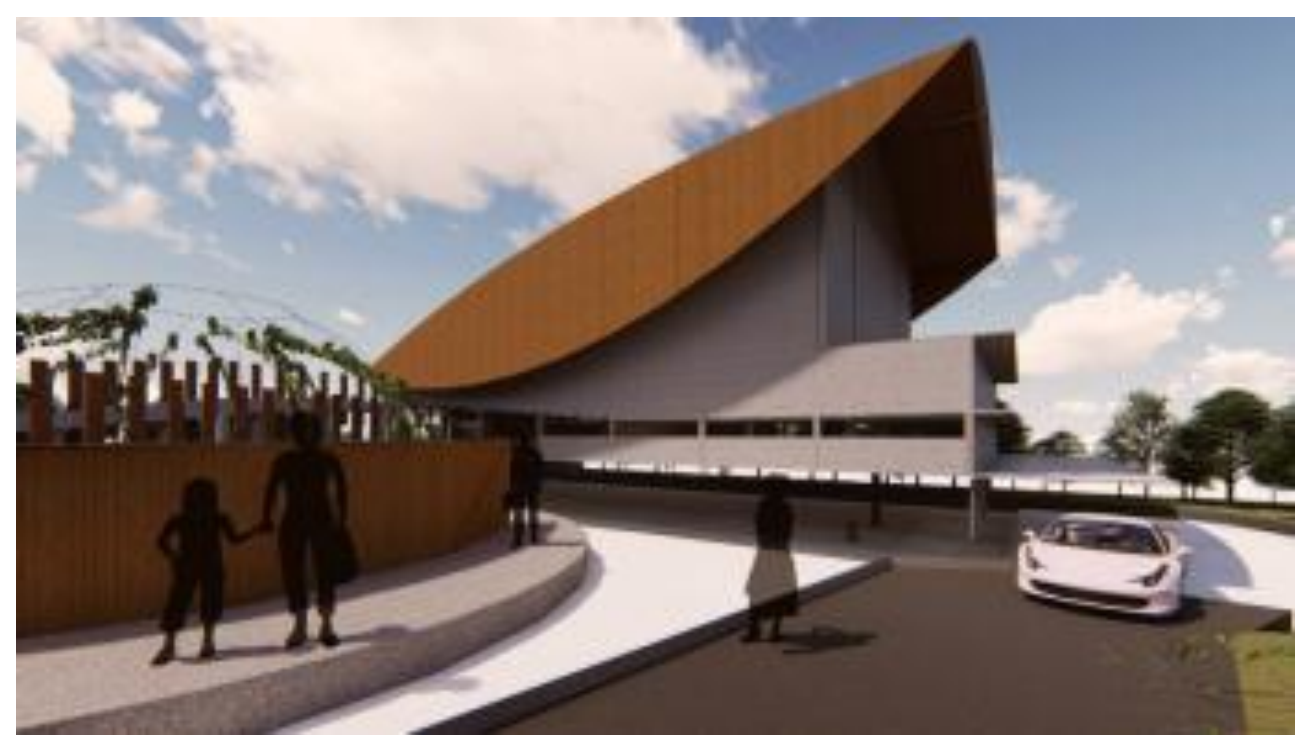

Gambar 12. Human View 


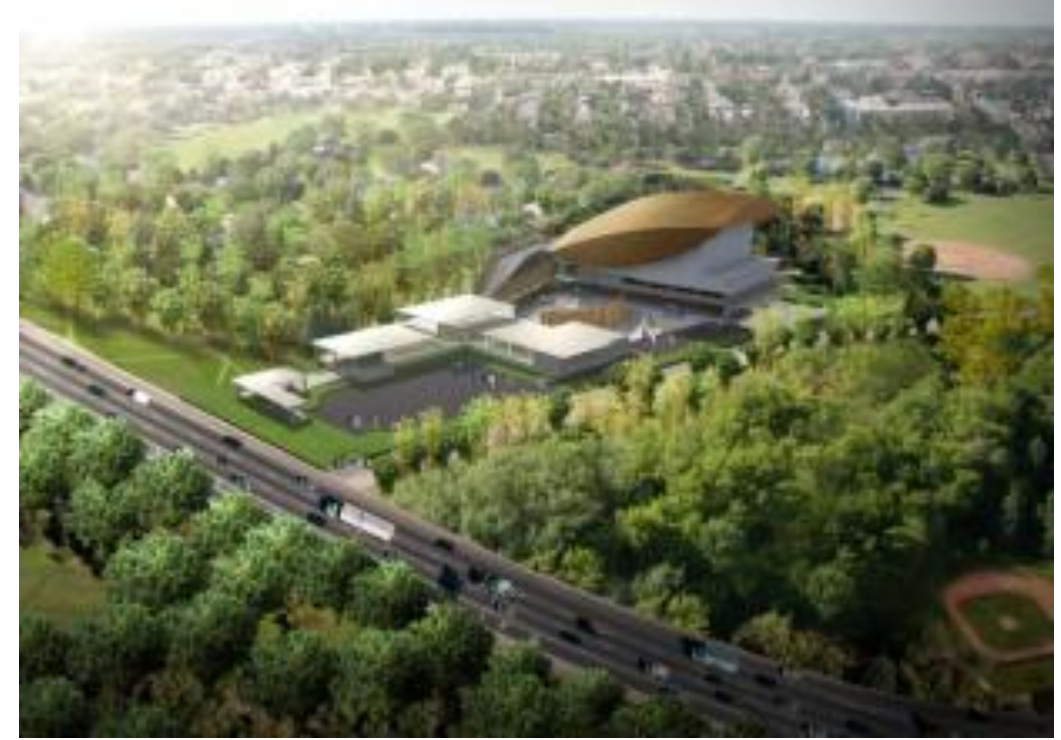

Gambar 13. Bird Eye View

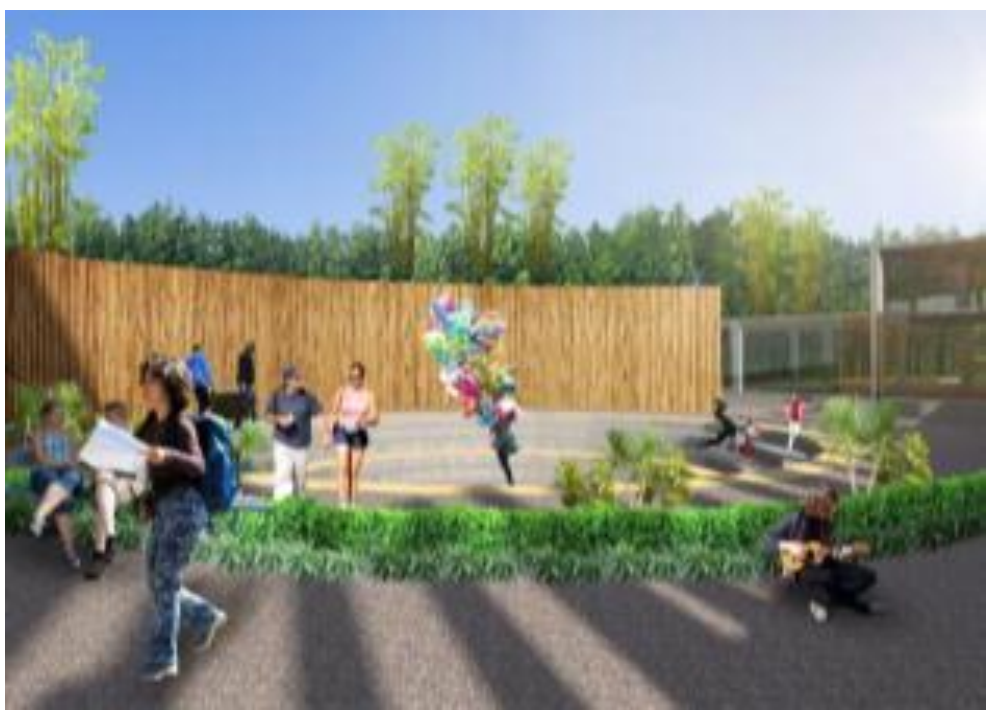

Gambar 14. Amphitheater

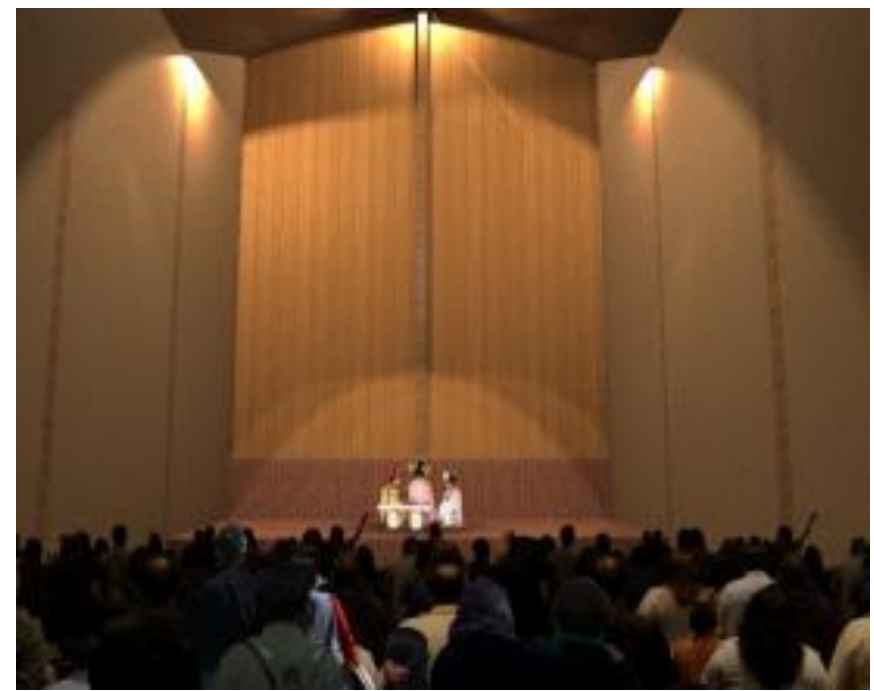

Gambar 15. Interior Ruang Pagelaran Seni 


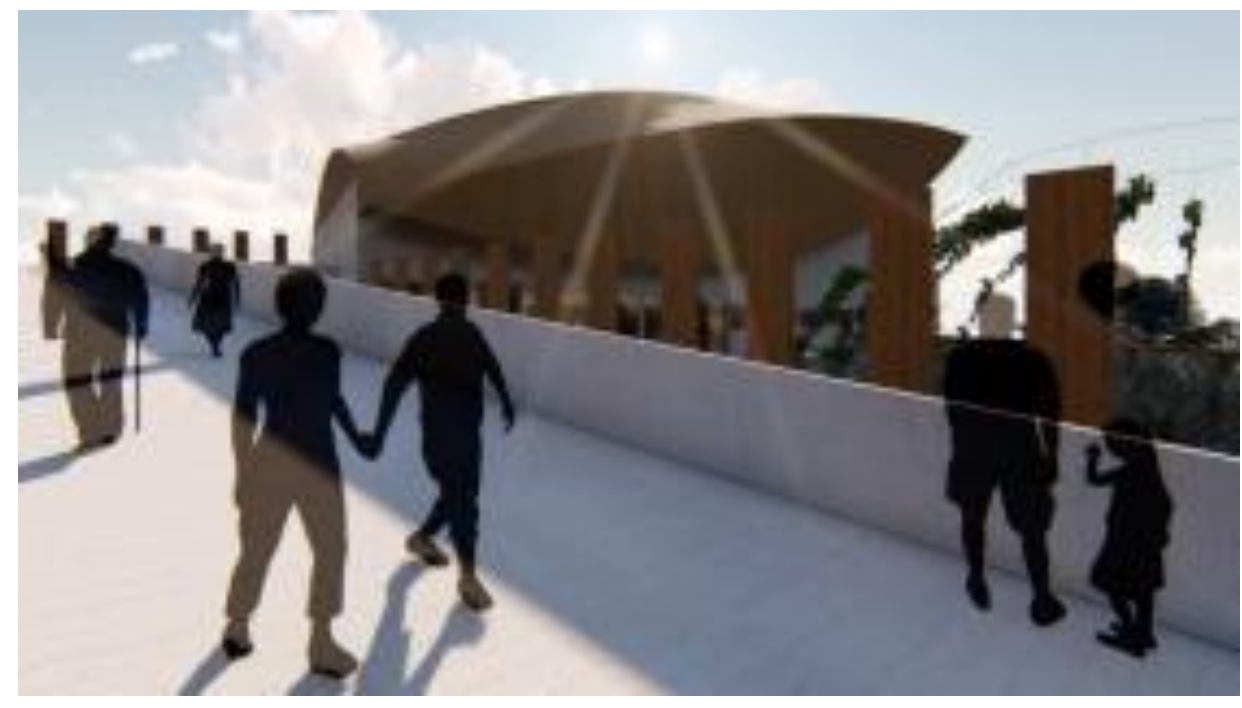

Gambar 16. Suasana Jembatan

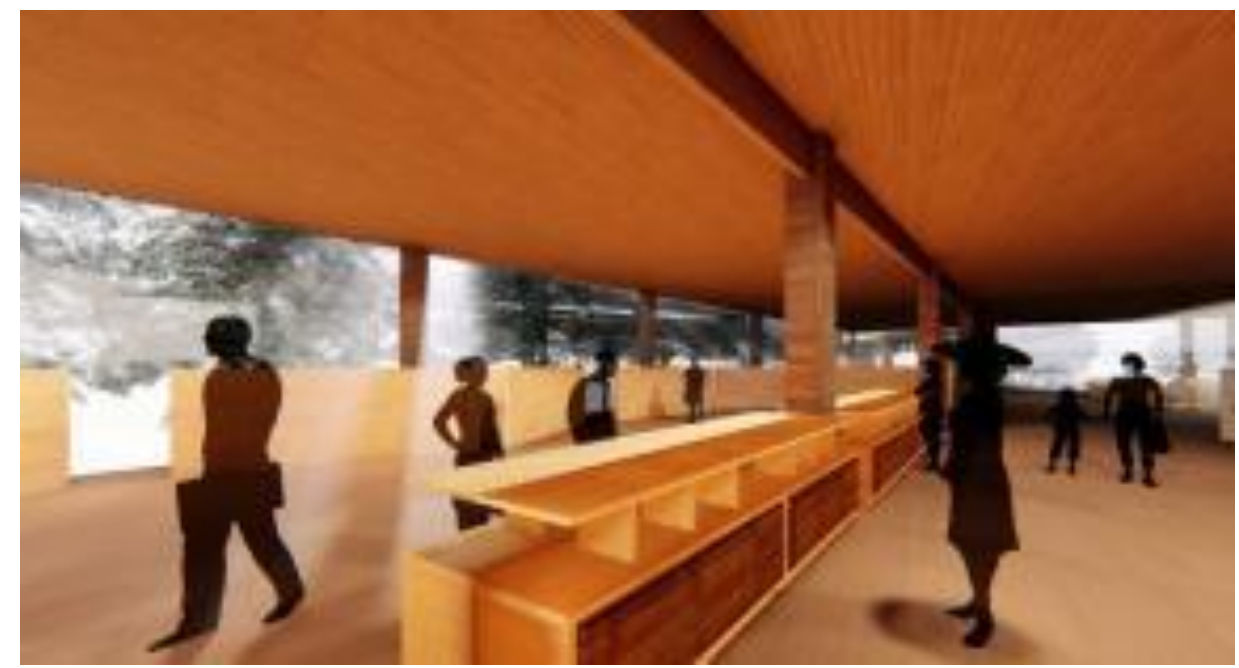

Gambar 17. Souvenir Shops

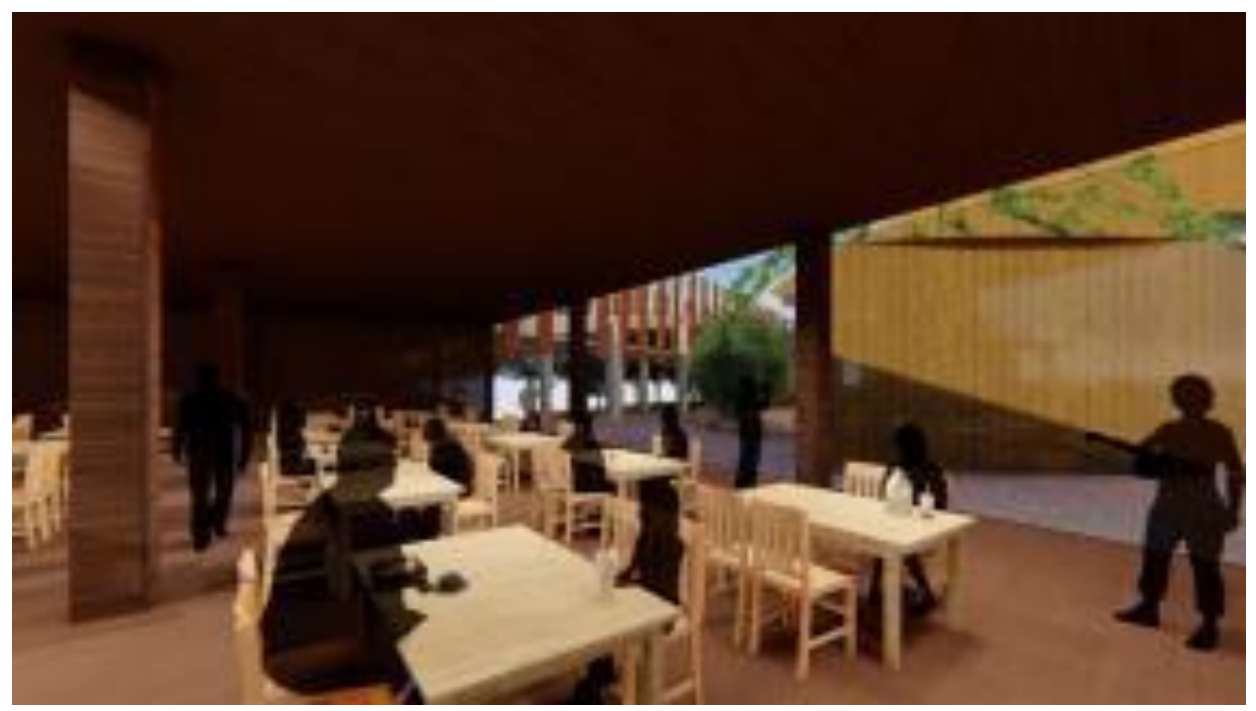

Gambar 18. Cafetaria 


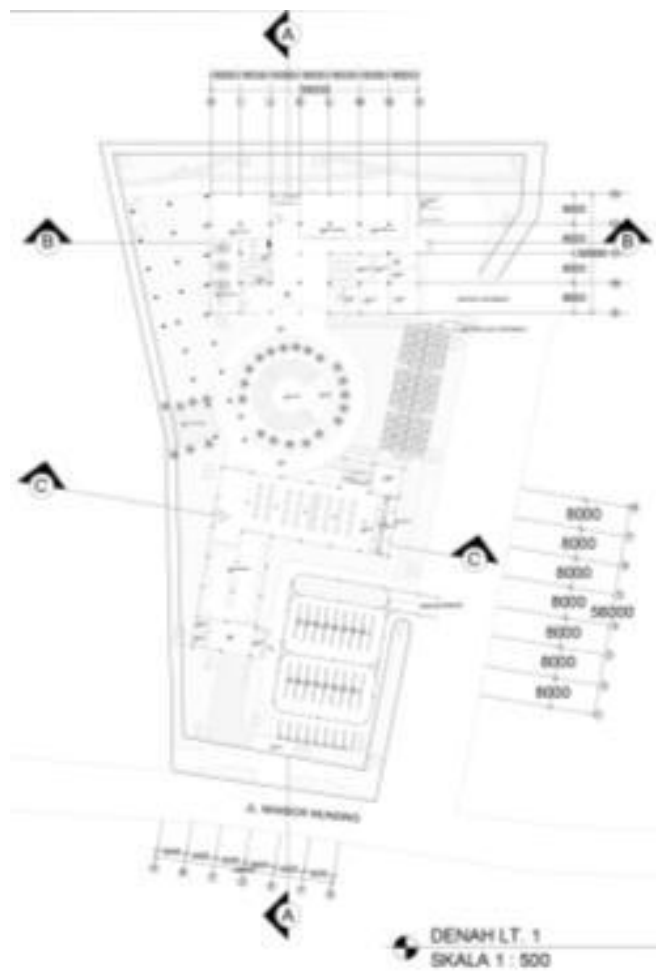

Gambar 19. Denah Lantai 1

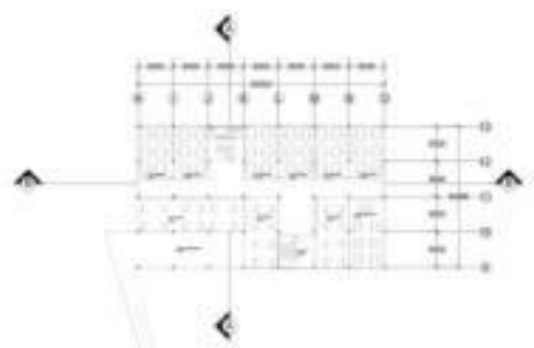

DENAHLT 2

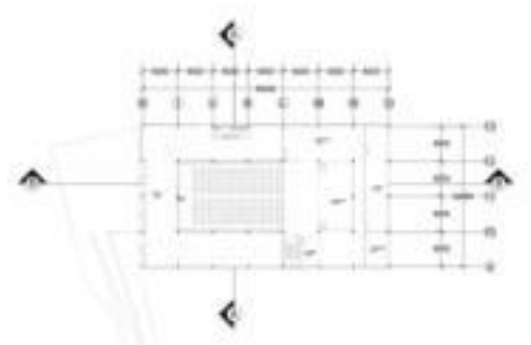

DENAHLT. 3

SKALA 1:500

Gambar 20. Denah Lantai 2 dan 3 


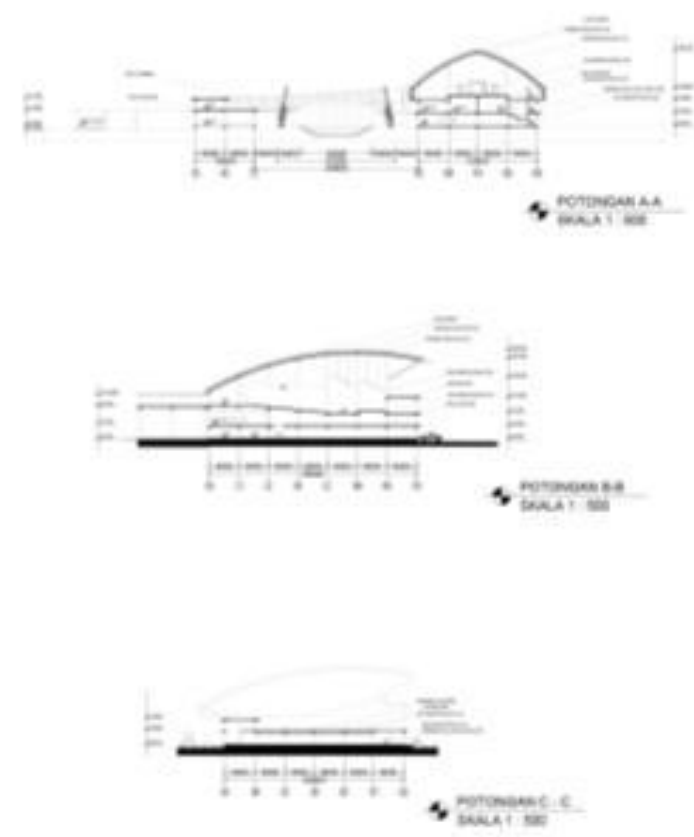

Gambar 21. Potongan Bangunan

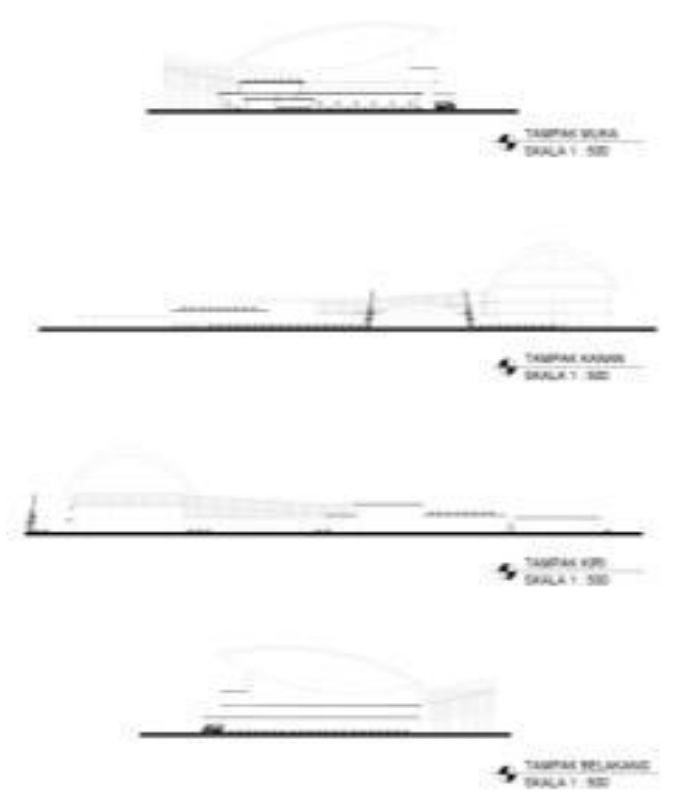

Gambar 22. Tampak Bangunan

\section{KESIMPULAN DAN SARAN}

Sentra Budidaya dan Kreasi Musik Bambu merupakan proyek pariwisata yang juga memperhatikan kondisi lingkungan setempat dan mendukung pembukaan lapangan kerja untuk masyarakat sekitar sehingga kondisi ekonomi setempat juga terbantukan. Selain itu, proyek ini juga mengangkat potensi sumber daya alam setempat yang tidak terekspos menjadi daya tarik pariwisata bagi masyarakat Jakarta maupun luar Jakarta, sekaligus menjadikan satu rangkaian edu-tourism di Jakarta Timur dengan Taman Mini Indonesia Indah dan Museum Lubang Buaya. Mengingat jumlah penduduk usia produktif di Kelurahan Cipayung terbanyak, tetapi tingkat penganggurannya juga tinggi. Oleh karena itu, proyek ini dapat menjadi salah satu cara untuk meningkatkan lapangan kerja masyarakat dengan meningkatan potensi sumber daya setempat juga. Proyek ini juga memberikan edukasi berupa pelatihan budidaya dan pengolahan bambu dari awal hingga menjadi barang jadi yang dapat dipasarkan. 
Proyek ini berlokasi di Jakarta Timur yang merupakan salah satu jalur masuk pariwisata, yaitu Bandar Udara Halim Perdanakusuma dan juga area edu-tourism di Jakarta, sehingga menjadi salah satu daya tarik untuk mengembangkan daerah Jakarta Timur di bidang Pendidikan non akademik, keterampilan, dan seni, Hasil rancangan proyek ini dikaji dari metode perancangan desain people focused dengan pendekatan kepada pemusatan kebutuhan manusia. Hasilnya dapat dilihat pada program - program aktivitas yang memusatkan kepada kebutuhan pengunjung, dan juga zoning pada tapak yang berdasarkan sirkulasi pekerja dan pengunjung.

\section{REFERENSI}

Akinlabi, Esther Titilayo. (2017). Bamboo : The Multipurpose Plant. Switzerland : Springer International Publishing.

Liese, Walter dan Kohl, Michael. (2015). Tropical Foresty. Switzerland : Springer International Publishing.

Minke, Gernot. (2016). Building with Bamboo : Design and Technology of a Sustainable Architecture. Swiss : Birkhauser

Neufert. (2012). Neufert Architects' Data. United Kingdom : Blackwell Publishing Ltd.

Rossi, Aldo. The Architecture of the City. London : The MIT Press.

Specth, Jan. (2014). Architectural Tourism Building for Urban Travel Destinations. Munich : Springer Gabler.

Sereli, Silvia dan Maciocco, Giovanni. Enhancing the City. New York : Springer Dordrecht Heidelberg.

Xiao, Yan. (2008). Modern Bamboo Structure. Great Britain : Cromwell Press.

Yoshikawa, Isao. (2009). Bamboo Fences in Japan. China : Princeton Architectural Press.

Ilmuseni.com diakses pada 12 Agustus 2018

Studipariwisata.com diakses pada 18 Agustus 2018

Netralnews.com diakses pada 19 Agustus 2018

https://sarasvati.co.id/news/11/membaca-masa-depan-bambu/ diakses pada 1 September 2018

http://www.bambunusaverde.com/bahasa/prospek-perkebunan-bambu.htm diakses pada 4 September 2018)

https://www.liputan6.com/news/read/2536220/merasakan-sejuk-hutan-kota-di-tengahbelantara-jakarta diakses pada 4 September 2018

http://www.satuharapan.com/read-detail/read/gereja-kristen-jawa-bambu-angkat-nilai-lokal diakses pada 4 September 2018

https://www.archdaily.com/81585/the-green-school-pt-bambu/5012b12f28ba0d147d00048athe-green-school-pt-bambu-photo diakses pada 5 September

https://www.archdaily.com/641170/sharma-springs-

ibuku?ad_medium=widget\&ad_name=more-from-office-article-show diakses pada 4 September 2018

http://wowasiknya.com/alat-musik-dari-bambu/ diakes pada 5 September 2018

http://www.academia.edu/9369781/keunggulan_dan_kekurangan_bambu diakses pada 6 September 2018

http://sahabatbambu.com/blog/post/bangunan-bambu diakses pada 6 September 2018

https://karyatulisilmiah.com/bambu/ diakses pada 6 September 2018

https://wancik.wordpress.com/2009/03/28/kelebihan-dan-kekurangan-material-bahan-

bangunan/ diakses pada 6 September 2018

https://rumahlia.com/tips-trik/info-dasar/kelebihan-dan-kekurangan-bambu diakses pada 6 September 2018 